\title{
Postmodern Apocalypse in White Noise and London Fields
}

\author{
Neda Khodadadegan \\ English Department, Faculty of Modern Languages and Communication, University Putra Malaysia, Malaysia \\ Hardev Kaur \\ English Department, Faculty of Modern Languages and Communication, University Putra Malaysia, Malaysia \\ Ruzbeh Babaee (Corresponding author) \\ English Department, Faculty of Modern Languages and Communication, University Putra Malaysia, Malaysia \\ E-mail: ruzbeh_babaei@yahoo.ca
}

Received: 29-01-2016

Published: 01-07-2016
Accepted: 14-04-2016

doi:10.7575/aiac.ijalel.v.5n.4p.65
Advance Access Published: May 2016

URL: http://dx.doi.org/10.7575/aiac.ijalel.v.5n.4p.65

\begin{abstract}
Postmodern Apocalypse is considered as a strategy a writer employs to depict the dreadfulness of nuclear disaster. It is a rich way of transmitting ideas of catastrophe and fear into a more meaningful fiction about a teleological end. This study analyzes postmodern apocalypse in two selected novels, namely Don DeLillo's White Noise (1985) and Martin Amis's London Fields (1989). The term which refers to characters who cry their concern about the destruction of the world demonstrates a sense of apocalypse in a community of nuclear age. Both DeLillo and Amis show their fear of a nuclear explosion. The present study aims to present an apocalyptic reading of two selected texts through using in the 1980s.Elizabeth K. Rosen's Apocalyptic Transformation: Apocalypse and the Postmodern Imagination (2008).
\end{abstract}

Keywords: Postmodern Apocalyptic Literature, Apocalypse, Post-Hiroshima era

\section{Introduction}

Traumatic historical events such as the Holocaust and the Vietnam War are deeply rooted in our collective consciousness. The recurrent anxiety of another destructive event in the contemporary world has not disappeared yet due to the prevalence of nuclear weaponry and terrifying forces of destruction. The nightmare of the two World Wars left the world frightened by another challenge of the same sort during the $1980 \mathrm{~s}$, in a way that much of the eschatological literature since Hiroshima has concentrated on the nuclear explosion as the new agent of death.

The individual components of the apocalyptic fiction are traced back to the ancient civilizations of Egyptians, Greeks, Vedic Indians, Persians, and Mesopotamians. The Book of Daniel is considered as the most notable apocalyptic story in the Old Testament which depicts the construction of New Jerusalem and the notions of a specific last judgment (1). In the Book of Revelation, apocalypse is referred to the struggle between good and evil and God's final judgment upon all souls. Traditional apocalyptic literature is considered as a device to comfort people whose lives were overwhelmed by social or historical disruption as well as an attempt by a culture which was deeply confused to comprehend itself in its own period. Its main purpose was to encourage its audience to maintain faith in hard times and to assure them that their faithfulness would be rewarded and their enemies would be diminished (1).

Postmodern apocalyptic literature is a portrayal of societies which are morally ruined and this corruption is often depicted in the form of a literal end caused by an atomic bomb or another nuclear event. Rosen calls apocalyptic literature the "grandest sense-making structure" which asserts human's need for shape and meaning. White Noise and London Fields depict a sense of an end in America and England, showing how the recurrent fear of an atomic event is not likely to disappear after years from the first atomic explosion. The purpose of this study is to examine traditional apocalyptic concept of apocalypse in the postmodern settings of White Noise and London Fields.

\section{Conceptual Framework}

\subsection{Apocalyptic Literature}

Traditional apocalyptic literature has never stopped to appear in secular works of literature. During the 1980s, critics who had studied the field noted a second branch in the family of apocalyptic literature. Rosen's study indicates how some contemporary writers have continued to engage with the traditional myth. These writers, who are called postmodern apocalyptic writers, have been attracted to the elements of hope inherent in the traditional model, though their postmodern style of storytelling or their own lack of religious faith that forces them to figure the message of hope in other terms. The reemergence of the traditional apocalyptic literature seems to be the result of the approach to the end of the century according to Rosen: 
Renewed religiosity coupled with recent anxiety about the approaching end of the second Christian millennium may in part account for an intensified interest in the eschatological vision in general, but what accounts for the renewal interest in the traditional apocalyptic paradigm specifically?... a growing climate of fear and an equally powerful sense that the paradigms by which we have tried to understand and interpret our world have come to seem inadequate and presumably unstable. (1).

The psychological need to make sense of the catastrophic world in which we live arouses a critical response on the part of artists. The paradox is that the traditional apocalyptic narrative stresses that no social reform can cure the corrupted world and accepts that only an absolute, "purifying cataclysm" can make it new and perfect world. However, what is important in creating postmodern apocalyptic literature is not that writers use the traditional apocalyptic paradigm, but that they manipulate it to make rich observations of the current world as it exists. Hence, the intention is not merely to rework the paradigm, but to use it as a means of social criticism (Rosen, 1).

In Postmodern Apocalypse: Theory and Cultural Practice at The End (1995), Richard Dellamora provides a collection of apocalyptic narrative and argues that the uncircumscribed field of narrative at the end of the millennium continues to be structured in relation to apocalypse in its traditional manifestation (4). Moreover, Josef Broeck declares that the apocalyptic genre has distanced itself from its biblical and historical roots due to the fact that there seems to be no agreement on the form, content, or function of apocalyptic writing and thinking in present-day narratives (5). Additionally, D.H Lawrence's Apocalypse and the Writings on Revelation (1980) is a thorough criticism of the political, religious and social norms in Western civilization. Lawrence's belief in humanity's power to redeem the spiritual values which alone can recover our world makes apocalypse a powerful statement of hope (6). Such an approach is more apparent in David Ketterer's reinterpretation of New Jerusalem in New Worlds for Old: The Apocalyptic Imagination, Science Fiction, and American Literature (1974) (7).

While some critics are more likely to continue with the elements of hope and renewal in their studies of the genre, most contemporary scholars of the field aim to concentrate on the role of the postmodern life and the crisis it has brought about in the formation of postmodern apocalyptic literature. In "No Apocalypse, Not Now", Jacques Derrida has an exceptional argument about the pervasiveness of nuclear weaponry and alarming forces of destruction that have been stockpiled and capitalized everywhere to establish the very sense of capitalization (8). Furthermore, in After the End: Representations of Post-Apocalypse (1999), James Berger wisely fixes on the idea of crisis when he writes that the sense of continuous crisis coexists with the notion that the apocalyptic catastrophe has already happened and the apocalyptic writing is only a reminder of some confusing catastrophe (9). In the fourth talk of The Sense of an Ending, "The Modern Apocalypse", Kermode also contends that the apocalyptic myth has continued to give us an opportunity to make sense of the world we are living in. He argues that there must be a link between the forms of literature and other ways in which we try to give some kinds of order and design to the past, the present and the future (10).

\subsection{Apocalyptic Themes and Motifs}

In Apocalyptic Transformation, Rosen refers to the writers and filmmakers who have appropriated the apocalyptic myth by applying a postmodern approach. Due to the fact that apocalyptic genre has religious roots, it is challenging for secular authors to adapt it to their postmodern narrative. In the traditional apocalyptic plot, God is the central figure and judgment is his major action in the end. The result of God's final judgment is the total destruction of the whole world, and the creation of a revitalized world which is known as the New Heaven on Earth. The significant challenge here seems to be in one hand translating the only power figure and the new world into secular terms, and removing the story of apocalypse from its theological setting. In spite of all these challenges, postmodern adaptations of the traditional paradigm have managed to retain all basic concepts of catastrophe, judgment, and deity" (1).

\subsection{Apocalypse}

According to Rosen, apocalyptic writing is a branch of prophecy; however, it is different from prophecy in its vision of history and mankind's role in it. God's prophet reproves sinful behavior and threatens punishment if the community does not correct its manner. He predicts a future which may occur if man does not follow God, and may be avoided if man returns to God (1). Traditional apocalypse, on the other hand, sees God's plan as fixed; God will destroy the whole world as a part of his plan. Apolcalyptists warn of an unchanging end. In this regard, the aim of them is to comfort and prepare the ones who are already saved. There is nothing to do to change God's plan, but only to endure it (1).

In postmodern representations of apocalyptic narratives, apocalyptists are different since they can only cry their warnings about the apocalyptic disaster which is still in the future. Apocalyptic prophet knows that "something is coming" (Rosen, 1); he is "messanically involved" (Rosen, 1) in articulating some of the sophisticated responses to imminent apocalypse. In line with this, a true apocalyptist, according to Rosen, "yearns for the end, knowing that New Jerusalem awaits the faithful after the last judgment. This one has a sense of dissatisfaction and frustration that is born of his recognition that the promised New Jerusalem meant to follow the end has slipped away" (1).

\section{Apocalypse in White Noise and London Fields}

White Noise has been called an apocalyptic novel by several critics who all agree about its depiction of a potential annihilation and the eternal fear of death. Dana Philips, for instance, refers to the end of history in analyzing one of the novel's scenes. She states how there is an absence of the sense of renewal and regaining the lost things, and how the 
"apocalyptic products" mark the end of nature and henceforward the end of our culture (11). Peter Boxall's study has also a chapter named "Death and the Avant-garde", in which he brings a number of episodes from White Noise to indicate the novel's depiction of death and the terror it carries into the life of its characters. He uses Freud's Beyond the Pleasure Principle to carry out his examination of these scenes and to mark how the plot of White Noise in line with every other plot tends to move deathward (12). His study becomes more straightforward in terms of its apocalyptic approach calling the toxic event which forms the central episode of the novel, "omnipotence of death" (12). Stacy Olster, is another critic whose study of White Noise has an analysis of its apocalyptic elements. Despite the two previous essays, Olster contends how knowingly the characters are engaged with the disastrous event which threatens their life. By comparing the poisonous cloud to the atomic bomb dropped on Hiroshima, Olster explains how the terror of an end has possessed the characters' mind (13). For Stephanie Halldorson, DeLillo's protagonist is, in many ways, the perfect American citizen. His style of life and his family structure are depicted to manifest a naturalized form of presence in a postmodern society. While, through a comparison between DeLillo's and Saul Bellow's hero, Halldorson reveals that they are heroes in the old mode who are playing the role of "a new false hero" (14).

Considering the mentioned studies on DeLillo's White Noise, it can be concluded that the writer depicts the modern American's useless search for the mystery of existence and their unsuccessful attempt to make sense of the meaningless world whose mystery is hopelessly elusive. Though failing to answer the riddles of the cosmos, the novel asks the rigid questions, and in doing so establishes an important original voice in temporary fiction. This is while the writer of this novel is unwilling to discuss his motives behind the creation of his work. In an interview conducted by LeClair, DeLillo says that it is in his nature to keep quiet about most things, even the idea in his work. He believes that an attempt to unravel a work belittles it in a way since it was created as a mystery in the first place (3).

Catherin Bernard puts Amis's London Fields, in the same category with Graham Swift's Waterland (1983) and Out of This World (1988) as metafictional novels that question and foreground the way we make sense of the world. She argues that like Swift, Amis is a postmodern writer because he presents the modern world's self-alienation and sense of loss, he undercuts the truth to show the provisional certainty in a world where uncertainty is the more common experience (15). Martians, Monsters, \& Madonna: Fiction \& Form in the World of Martin Amis was also written by John A. Dern and published in 2000 discussing postmodernism, modernism, and anti-modernism as disparate conditions combined in the novels of Amis (16). Nicola La Rose like Carlos Silva-Campanon examines the relationships established between characters who escape their cities to identify how Amis's characters wander aimlessly (17-18). While the major difference in their studies refers to a direct connection LaRose makes between the media and the subjectivity to manifest how digitized information makes "commodities out of individuality" (17). Amis's London Fields has not been analyzed through a postmodern apocalyptic approach so far, though there has been studies on apocalyptic features in the novel as mentioned before. Hence, this study will attempt to extend, with more details, an examination of postmodern apocalyptic features presented by Rosen on Amis's London Fields to manifest the everlasting nuclear fear in the English society.

\subsection{The depiction of Apocalyptists}

According to Rosen, apocalyptists are characters who know something is going to happen and cry their warnings before it really happens (1). She mentions that "apocalyptist can exist in the face of the impending apocalypse and the sheer number of them is due to the pervasive sense of imminent ending which is the result of living under the shadow of the nuclear bomb" (1). Rosen's description of apocalyptic characters is perceivable both in White Noise and London Fields which represent more than one apocalyptist in their portrayals. Both novels are structured around a disconfirmed apocalyptic event and give some of their characters an opportunity to meditate on apocalyptic expectations. In both novels, there are characters who directly express their warnings either through their philosophy about life or through their actions. Both DeLillo and Amis also create characters whose portrayal symbolizes the thread of a disastrous event rather than their speech, tact and thoughtfulness. These characters who are mainly young children are not able to logically express their warning and only have the ability to scream it out, each in their own way.

In the last chapter of Apocalyptic Transformation, Rosen makes an attempt to signify the apocalyptists of White Noise. She asserts that the novel's only apocalyptic character is Wilder, Jack's and Babette's youngest child. To prove this, she refers to Wilder's unusual silence throughout the novel which is suddenly broken by his seven-hour crying jag described as a 'lament', an 'ancient dirge all the more impressive for its resolute monotony" (1). This episode gives enough evidence to categorize Wilder as an apocalyptist who does not talk his concerns, but rather cries them out. Rosen also refers to the child's name which recalls the biblical wilderness where prophets sometimes wander. This association is strengthened by Jack's observation, according to Rosen:

It was as though he'd just returned from a period of wandering in some remote and holy place, in sand barrens or snowy ranges- a place where things are said, sights are seen, distances reached which we in our ordinary toil can only regard with the mingled reverence and wonder we hold in reserve for feats of the most sublime and difficult dimensions (1).

In the final episode of the novel, Wilder is explained driving his tricycle across a crowded highway without getting hit by any of the cars. This scene also implies that he is a prophet figure protected by God from injury (1). Wilder as a child symbolizes the Messiah figure, whose worries are announced through the depiction of his actions rather than his wise and philosophical ideas about technology and its threat to man's life. 
In White Noise, there are other apocalyptists who inform the readers about the stealthy menace of either an ecological or moral destruction, mainly by transferring their message through literal speeches. These apocalyptic characters are Heinrich, Jack's elder son from one of his previous marriages, who is overloaded with scientific and technological information and Murray Jay Siskind, a guest lecturer at College-on-the-Hill who continuously warns his students and his colleague, Jack, of the presence of the "modern death" which has occurred in result of capitalism (19).

Heinrich, at fourteen, is an apocalyptic teenager whose role is portrayed through his speeches which carry the message of dread and corruption. The most significant sign of Heinrich's prophetic existence is that the toxic cloud is first spotted by him and he is the one who starts repeating it, from media, through several terms and expressions such as "a heavy black mass hanging in the air beyond the river, more or less shapeless" (19), "feathery plume" (19), "strange.. like a shapeless growing thing", and "a dark black breathing thing of smoke" (19). Heinrich's descriptions do not limit to the toxic cloud but go beyond this event to portray the technological threats in our everyday life. He informs his family that radiation from electronic devices is more dangerous than the perceived toxic cloud (19). In "From Tombstone to Tabloid", Mark Conroy expresses that nobody knows if Heinrich is right or wrong and he is only the possessor of scientific discourse (20). This shows how this character is portrayed to convey the message of scientific threats. Heinrich expresses his apocalyptic warning by reminding his father of human perceptual limits: "Just because you don't hear a sound doesn't mean it's not out there ... they [sounds] exist in the air, in waves. Maybe they never stop. High, high, high-pitched. Coming from somewhere" (19).

Heinrich is similar to Wilder in playing a Messianic role to provide for his fellows this special human mediation. It is shown in an episode where Gladney family is out of town with many other people who have left their hometown to escape the toxic cloud. Heinrich is surrounded by confused people who try to make sense of the threatening chemical event. Heinrich, whose face is shining in the light is seen by Jack while describing the event to the confused:

What a surprise it was to ease my way between people at the outer edges of one of the largest clusters and discover that my own son was at the center of things, speaking in his new-found voice, his tone of enthusiasm for runaway calamity. He was talking about the airborne toxic event in a technical way, although his voice all but sang with prophetic disclosure. He pronounced the name itself, Nyodene Derivative, with an unseemly relish, taking morbid delight in the very sound. People listened attentively to this adolescent boy in a field jacket and cap (19).

In this scene, DeLillo makes a portrayal of a young man who has undoubtedly influenced his listeners by his age. He is believed to be truthful and earnest, serving no special interest. He has an awareness of the environment and looks quite confident and influencing in conveying his knowledge.

In White Noise, Murray who is Jack's new colleague at university has a large and complex role. As a guest lecturer, he has been offered to teach courses on Elvis Presley and car crash movies. In "Closing the Loop: White Noise", LeClair describes Murray as "deciphering, rearranging, pulling off the layers of unspeakability in popular culture and eventually in Jack's life" (21). Murray's method is to "root out the content" by explaining and warning Jack about everyday events in an American life. The title of the first chapter "Waves and Radiation" is first mentioned by him, as an example. By creating such a phrase, Murray gives an expression to define the real nature of today's world which is encircled with the hazard of technological inventions and developments. His certainty of a coming disaster is conveyed through the major statement in his speech: “it's obvious" which he uses repeatedly throughout the story. But Murray's Messianic role is intensified once he extends his warnings beyond the borders of a physical damage. He tells his students:

You are spinning out from the core, becoming less recognizable as a group, less targetable by advertisers and mass-producers of culture. Kids are a true universal. But you're well beyond that, already beginning to drift, to feel estranged from the products you consume. Who are they designed for? What is your place in the marketing scheme? Once you're out of school, it is only a matter of time before you experience the vast loneliness and dissatisfaction of consumers who have lost their group identity (19).

All that Murray is doing is declaring the dominant, the deadly serious principles of a capitalist society. His speech shows how the marketing scheme works in a capitalist system and how hard it is for the individuals to believe in the true awfulness of such systems. He believes the individuals of a capitalist society are fragile creatures surrounded by a world of hostile facts which threaten their security and happiness. Murray's perspective towards such structures is manifested in this dialogue he has with Jack:

The deeper we delve into the nature of things, the looser our structure may seem to become. The family process works toward sealing off the world. Small errors grow heads, fictions proliferate. I tell Murray that ignorance and confusion can't possibly be the driving forces behind family solidarity. What an idea, what a subversion. He asks me why the strongest family units exist in the least developed societies (19). 
Hence, Murray can be considered as the main prophetic figure of White Noise who warns Jack, his students, and finally the reader about the main threat of the contemporary world; capitalism which murders our individuality rather than our physical existence.

In London Fields, there is little doubt that Nicola Six is the prophet of the end. According to Rosen, a true apocalyptist yearns for an end and has a sense of dissatisfaction and frustration that is born of his recognition that the promised New Heaven has slipped away (1). This frustration and longing for the end is obviously perceivable in Nicola who screams the death of love, witnesses the gradual death of earth, and finally plans her own murder. Her messianic characteristic is depicted mainly through her visions. Right from the start, from the moment that her thoughts began to form, Nicola knew what was going to happen next. When she was four years old, as an example, she saw the warnings of a concentric devastation on television. According to the news, London was threatened by a catastrophic event and Nicola knew that it would happen in the form of a nuclear explosion and she knew that it was just a matter of time (22). In another episode, it is stated that although Nicola did not spend any of her time going to church to give her an interest in religion, she often saw herself going out with God (22). Nicola's religious portrayal is tied with blasphemy, placing a Christian apocalyptic messiah figure in a corrupted postmodern context. The heavenly presence of God is unexpectedly damaged by Nicola's imaginations of sleeping with him and manipulating him just as she does with male characters of the novel. Nicola who compares herself to virgin Marry and is called "the miracle" (22) by Samsun, sees in her dreams that God wants to marry her and have her come and live with him at His place which is heaven, and this could be achieved very easily because God had said he would fix it so she could live with him forever (22).

Undoubtedly, Nicola as a postmodern prophetic figure has postmodern warnings which are mainly depicted in her concerns about the planet earth and death of love. She believes that human beings have turned the earth's hair white:

She seemed to have eternal youth but now she's ageing awful fast, like an addict, like a waxless candle. Jesus, have you seen her recently'? We used to live and die without any sense of the planet getting older, of mother earth getting older, living and dying. We used to live outside history. But now we're all coterminous. We're inside history now all right, on its leading edge, with the wind ripping past our ears. Hard to love, when you're bracing yourself for impact (22).

Nicola has this idea that love is a savior and even she might have been saved by love, but she also has this awareness that she will never survive due to the power of corruption which has overshadowed love. She is given a messianic role as she is given the power to bring love everywhere, in any way. Her prophetic role turns out to be postmodern due to the fact that she refers to love as "postmodern love" and the one that she is certain to give to men and not women. The complexity of Nicola's apocalyptic depiction lies in Amis's reluctance to give morality an absolute definition. Nicola claims that by giving love to men she gives their world high color, but soon confesses that she "couldn't generate it or send it out" (22). Amis gives his lesson through loveless life of Nicola who expands her emptiness to the whole modern world: "And if love was dead or gone then the self was just self, and had nothing to do all day but work on sex. Oh, and hate. And death" (22).

As an apocalyptist, Nicola has an opportunity to cry her warning not only through her philosophical mind, but also through her actions. In her childhood, Nicola had a little friend whose name was "Enola Gay" (22). She had come from inside the head of Nicola and never existed in reality. Enola also had this gift of always knowing how things would unfold. Enola Gay grew up with Nicola, and later on in the story we learn that she has been raped and given birth to a baby boy called "Little Boy" (22).

On the surface, it is believed that these are two imaginary characters created by Nicola as a cheating device to play tricks on Guy; later on as the story goes on, it is revealed that these are not just two mind- made characters, but real disastrous entities. Enola Gay is a Boeing B-29 Super fortress bomber, named for the pilot's mother, Enola Gay Tibbets (23), during the final stages of the Second World War. It became the first aircraft to drop an atomic bomb in the history of bombardment. The bomb, which was code-named Little Boy (23), was targeted at Hiroshima in Japan, and caused unimaginable destruction. Enola Gay also took part in the second atomic attack as the weather reconnaissance aircraft for the primary target of the city Kokura, but the clouds and drifting smoke resulted in Nagasaki being bombed instead. The two imagined characters then, are representatives of a coming disaster which in this case is supposed to be another nuclear explosion. By using real threatening agents of modern death and destruction, Nicola proves herself to be the messenger of the everlasting nuclear threats.

In addition to Nicola Six whose warnings are conveyed mainly through the depiction of her philosophical mind, London Fields presents its second apocalyptist as a figure whose depiction symbolizes the coming catastrophe, rather than his point of view. Marmaduke, the child of Guy and Hope, is a child-monster who sinks his teeth into anyone, sexually attacks his nannies, and has a special affection for blinding pokes at Guy's eyes, followed by paralyzing blows to Guy's genitals. Guy, however, "loves Marmaduke despite the clear sense, constantly refreshed, that Marmaduke had no lovable qualities. Marmaduke gave no pleasure to anyone except when he was asleep" (22).

Like Wilder in White Noise, Marmaduke gains his prophetic role through exaggerated cries. It is mentioned that he would often take a brief nap around midnight; the rest of the time he spent screaming (22). James Diedrick has said about London Fields that it "feeds on the death of all cherished beliefs" (24). One of these cherished beliefs is that children are nice and innocent, and Amis contributes to this picture by making Marmaduke, who is accurately stripped 
of any niceness normally attributed to childhood. After his birth, his parents reflect: "for years they had worried about the kind of world they were bringing their child into. Now they worried about the kind of child they were bringing into their world" (22). Consequently, "their last attempt at lovemaking had featured the pill, the coil, the cap and three condoms, plus more or less immediate coitus interrupts. That was July. This was September" (22).

The coming disaster which in London Fields is a nuclear war or explosion is intensified and warned where Mamaduke's situation is described by using a range of military terminology. He is cured, not by a "team of doctors" but by a "platoon of medical commandos" (22); his diapers are stated as "loaded or unloaded" (22), and his military toys, "the howitzers and grenade-launchers and cartridge belts [...] the plastic broadswords and cutlasses and scimitars," disclose a "disturbing literalism" (22) in the nursery by being not miniature but full size. Marmaduke is compared to NATO (22), whose provocative policy is to strike first in event of conflict. All these comparisons related to this apocalyptic figure lead us to Graham Fuller's suggestion that Hope and Guy's "little boy" (22) is an incarnation of Little Boy, the atom bomb thrown over Hiroshima. In this respect, both London Fields reveals its emphasis on the recurrent fear of a nuclear explosion in an after- Hiroshima world.

The apocalyptic message of destruction is conveyed through the philosophical minds of Murray in White Noise and Nicola in London Fields mainly centered to warn the readers about the deathly principles of modern life. The dreadfulness of such warnings albeit, lies in Wilder's and Marmaduk's crying and screaming. Old Germans remind Guy of Marmaduke (22) in London Fields, and Jack names his eldest son Heinrich in White Noise to make a fake protective device for himself against his fear of death. All references to German Nazis remind the reader of the most brutal massacred in the world of human history. They refer to the death of morality in the postmodern world where the sense of a coming disaster is accompanied with the vanishing human value.

\section{Conclusion}

In both White Noise and London Fields, apocalyptists are indubitably present, created in the body of a child or the philosophy of an adult. The messianic figure of White Noise is Wilder, who is fully protected by God, while in London Fields; it is the monster-child, Marmaduke. Wilder's warnings of a coming disaster are conveyed through his sevenhour crying. Marmaduke's uninterrupted cries and screaming as well as his pornographic desires are warnings about a morally failing society. This character is also described through the use of a range of military terminology and is compared to Germans to remind the readers of the greatest human wrongdoings during the two World Wars.

Adults also cry their warnings of a coming disaster, as is shown predominantly through their ideologies. Heinrich in White Noise reveals his prophetic role while sitting in the middle of a confused crowd with his shining face, explaining the toxic cloud. He is overloaded with scientific knowledge to describe the real threats of technological developments and human's perceptual limits. Murray, but, is the main prophetic figure since he warns the readers of the treats of the main deity figure, capitalism, and its power to marginalize its creatures. The adult apocalyptist of London Fields is Nicola whose role is obvious through her visions and ideologies. She compares herself to Virgin Marry, goes out with God, and is revealed to have visions since her childhood. Though, her warnings are basically postmodern and are cried through the death of love which seems to be the main destruction in London Field's secular world. What ties Nicola's warnings to a physical nuclear destruction, is her wise choice in calling her imaginary friend Enola Gay and her child Little Boy, both referring to the atomic bombardment of Hiroshima and Nagasaki.

White Noise and London Fields are stories in which man is responsible for his own destruction. They emphasize this destruction and give no suggestions of the presence of a better world to be inherited by the faithful in the end. In neither of the stories the complete destruction happens. In White Noise, Jack Gladney does not die from being exposed to the chemical cloud. In London Fields, a partial destruction happens through the death of Nicola Six and Samsun Young declaring the futility of existence and desperation of living in a corrupted society. The final scenes of both novels which is quite different from apocalypse as a myth, suggests a new interpretation of the whole postmodern paradigm.

Lack of an End, means lack of renewal which in traditional apocalyptic narratives is confirmed in the presence of New Jerusalem. The complete destruction as a cleansing means does not happen here, signifying that the corrupt world can never been cleansed. Rosen suggests that "New Jerusalem and the hope it symbolizes only exist outside reality"; it exists in the character's mind (80). This might be the main motivation behind Nicola's self-destructive approach. She feels desperate in a world which lacks love and leaves it, not in search of a better world; just in ending the suffering she is going through.

It can be concluded that lack of a purifying end exposes the apocalyptic paradigm through which the characters are able to make sense of a disordered world. When apocalypse is removed, a clear sense of good and evil is lost. The failure of a complete destruction in White Noise and London Fields, is in fact the failure of apocalyptic literature as a sensemaking device, and this is to intensify how corrupted and incurable the contemporary world has become.

\section{References}

Rosen, E.. (2008). Apocalyptic Transformation: Apocalypse and the Postmodern Imagination. Lexington Books. Lanham

Amis, M. (1993). Visiting Mrs. Nabakov and Other Excursions. Jonathan Cape. London

LeClair, T. (1982). An interview with Don DeLillo. Contemporary Literature, 23. 
Dellamora, R. (1995). Postmodern Apocalypse: Theory and Cultural Practice at the End. University of Pennsylvania Press. Pennsylvania.

Broeck, J. (1985). "The apocalyptic imagination in America; Recent criticism. The Kritikon Litterarum, 14, 89-94

Lawrence, D.H. (2001). Apocalypse and the Writings on Revelation. Cambridge University Press. Cambrigde..

Ketterer, D. (1974). New World for Old: The Apocalyptic Imagination, Science Fiction, and American Literature. Indiana University. Bloomington.

Derrida, J. (1984). 'No Apocalypse, Not Now (Full Speed Ahead, Seven Missiles, Seven Missives)'. Trans. C. Porter, P. Lewis, Diacritics, 14(2), Nuclear Criticism: 20-31.

.Berger, J. (1999). After the End: Representations of Post-Apocalypse. University of Minneapolis Press. Minneapolis Kermode, F. (1967). The Sense of an Ending . Oxford University.

Bloom, H. (2003). Don DeLillo's White Noise. Chelsea House Publisher.

Boxall, P . (2006). Don DeLillo: The Possibility of Fiction. Routledge.

Duvall, J. (2008). The Cambridge Companion to Don DeLillo. Cambridge University Press. New York.

Halldorson, S. (2007). The Hero in Contemporary American Fiction: The Works of Saul Bellow and Don DeLillo. Palgrave Macmillan. New York.

Bernard, C. (1993). Dismembering/Remembering Mimesis: Martin Amis, Graham Swift. British Postmodern Fiction. Postmodern Studies 7. Ed. Theo D'haen, Hans Bertens. Amsterdam: Rodopi: 121-44.

Dren, J. (2000). Martians, Monsters, \& Madonna: Fiction \& Form in the World of Martin Amis. Peter Lang Publishing. New York.

La Rose, N. (2006). Gangsters, zombies, and other rebels: Alternative communities in late twentieth-century British novels and films. University of Florida

Silvia-Campanon, C. (2004). Through the looking glass: America in Martin Amis's Money: A suicide Note. Atlantis 90.

Conroy, M. (1994). From tombstone to tabloid: Authority figured in White Noise. Critique, 35(2), 97-110

Le Clair, T. (1987). In the loop: Don DeLillo and the systems novel. University of Illinois Press.

Amis, M. (1989). London Fields . Vintage Books. New York

The Oxford Essential Dictionary of the U.S Military. Oxford University Press. Oxford. 2002.

Diedrick, J. (2004). Understanding Martin Amis. University of South Carolina. 